\title{
Variation of Soils Erodibility in Mbe Agropastoral Area in Relation with Land Utilization, Central Cameroon
}

\author{
Boukar Atougour ${ }^{1 *}$, Simon Djakba Basga ${ }^{2}$, Elisabeth Yaboki ${ }^{1,3}$, Jean Pierre Temga ${ }^{4}$, \\ Jean Pierre Nguetnkam ${ }^{1}$
}

${ }^{1}$ Department of Earth Sciences, Faculty of Science, University of Ngaoundéré, Ngaoundéré, Cameroon

${ }^{2}$ Institute of Agricultural Research for Development (IRAD), Garoua, Cameroon

${ }^{3}$ Institute of Agricultural Research for Development (IRAD), Ngaounderé, Cameroon

${ }^{4}$ Department of Earth Sciences, Faculty of Science, University of Yaoundé I, Yaoundé, Cameroon

Email: *boukaratour@gmail.com

How to cite this paper: Atougour, B. Basga, S.D., Yaboki, E., Temga, J.P. and Nguetnkam, J.P. (2019) Variation of Soils Erodibility in Mbe Agropastoral Area in Relation with Land Utilization, Central Cameroon. Open Journal of Soil Science, 9 , 269-283.

https://doi.org/10.4236/ojss.2019.912017

Received: October 9, 2019

Accepted: December 28, 2019

Published: December 31, 2019

Copyright $\odot 2019$ by author(s) and Scientific Research Publishing Inc. This work is licensed under the Creative Commons Attribution International License (CC BY 4.0).

http://creativecommons.org/licenses/by/4.0/

\section{(c) (i) Open Access}

\begin{abstract}
The study of the soils from Mbé and Wack is carried out in the framework of the knowledge of soils from the Adamawa Region of Cameroon and their erodibility was investigated using erodibility indices obtained through physico-chemical data. Eleven topsoils $(0-20 \mathrm{~cm})$ samples were collected on different land use and their susceptibility to erosion was assessed. The water dispersible clay $\left(34.92-121.75 \mathrm{~g} \cdot \mathrm{kg}^{-1}\right)$, the clay dispersion ratio $(0.45-0.84)$ and the dispersion ratio $(0.75-0.89)$ were high in the studied soils while the clay aggregation $\left(13.16-42.27 \mathrm{~g} \cdot \mathrm{kg}^{-1}\right)$ and the clay flocculation index $(0.16$ $0.55)$ were low to moderate indicating their high erodibility. The soils under natural vegetation, more clayey, displayed the highest amount of water dispersible clay while cropped soils recorded the smaller ones. Globally, in cropped soils, those under cereals displayed the highest clay dispersion indices than those under tubers. This suggests that tubers cropping practices in studied soils enhance their erodibility. Statistical analyses revealed that amorphous $\mathrm{Al}$ and $\mathrm{Fe}$ are elements which limit soils erodibility while $\mathrm{K}^{+}$and $\mathrm{NH}_{4}^{+}$promote soils particles dispersion. Sustainable management of these soils will consist on limiting runoff through agricultural practices such as direct seedling and orienting tillage perpendicularly to slope gradient.
\end{abstract}

\section{Keywords}

Mbé, Wack, Erodibility, Soil Properties, Land Use

\section{Introduction}

In the tropics, soil organic matter of major upland soils is low while many of 
such soils are predominated by coarse materials. They are highly susceptible to erosion caused by the highly erosive rainfall [1]. Erosion influences negatively the soils and the environment; it involves reduction of soils fertility (lowering of nutrients and organic matter) and soil structure degradation (compaction, structure modifications, crusting) [2]. It is observed that the soil was highly vulnerable to degradation irrespective of fallow management, cropping intensities or slope gradient and this would be worsened by highly erosive rainfall events. Moreover, inappropriate cultural practices are mainly the principal cause of soils degradation [2] [3].

Traditional agricultural systems, characterised by fallow for a short period do not assure sustainable management of natural resources and induce to a spiral of environment degradation [4]. Mbé and Wack, important agropastoral zones in North Cameroon (transition between soudanoguinean and soudanosahelian agroecological areas), are characterised by an expansion of shifting and burning agriculture, fallowing (after maximum three years for tubers and five years for cereals) and ridging. According to the Ministry of environment report [5], an introduction of cotton plants in the region, intensification of agropastoral activities, deforestation and the late burning lands require looking out of degradation process in this landscape.

Annual reports of the ministry of agriculture at Mbé show that from 2002 to 2010, while cultivated surface (S) increased about $42.54 \%$ (from 177.5 ha to 253 ha); annual production (P) also increased about $34.27 \%$ (581.07 to 780.2 tonnes) and annual ratio production per cultivated surface $(\mathrm{P} / \mathrm{S})$ decreased from 3.3 to 3.1; whether average yield or output decrease for 0.2. However, land overexploited by farming and breeding involves degradation of natural resources compromising productivity. It is noted that there are relationships between yielding, soil physicochemical properties and clay dispersion [2] [3] [6] [7] [8] [9]. Hence, the knowledge of soil resource susceptibility to erosion is prior to a sustainable utilisation. The objective of this study is to determine the impact of soil utilization to soil erodibility in agricultural zone from Adamawa, Cameroon. It consists to: 1) assess the erodibility of the soils from Mbe and Wack and 2) determine the influence of agricultural practices on their erodibility.

\section{Materials and Methods}

\subsection{Study Area and Sampling Techniques}

The study was conducted in Mbe subdivision mainly at Wack village and Mbe during dry season (Figure 1). The soudanoguinean climate with dry season from November to March and wet season from April to October prevails in the study area. The mean annual rainfall is $1500-2000 \mathrm{~mm}$ in this transition zone between the subhumid and dry climates. The mean annual temperature is $22^{\circ} \mathrm{C}$. However, the minimum temperature is between $10^{\circ} \mathrm{C}-19^{\circ} \mathrm{C}$ and it occurs during December and January. Then a maximum temperature is between $27^{\circ} \mathrm{C}$ $34^{\circ} \mathrm{C}$ in March. 


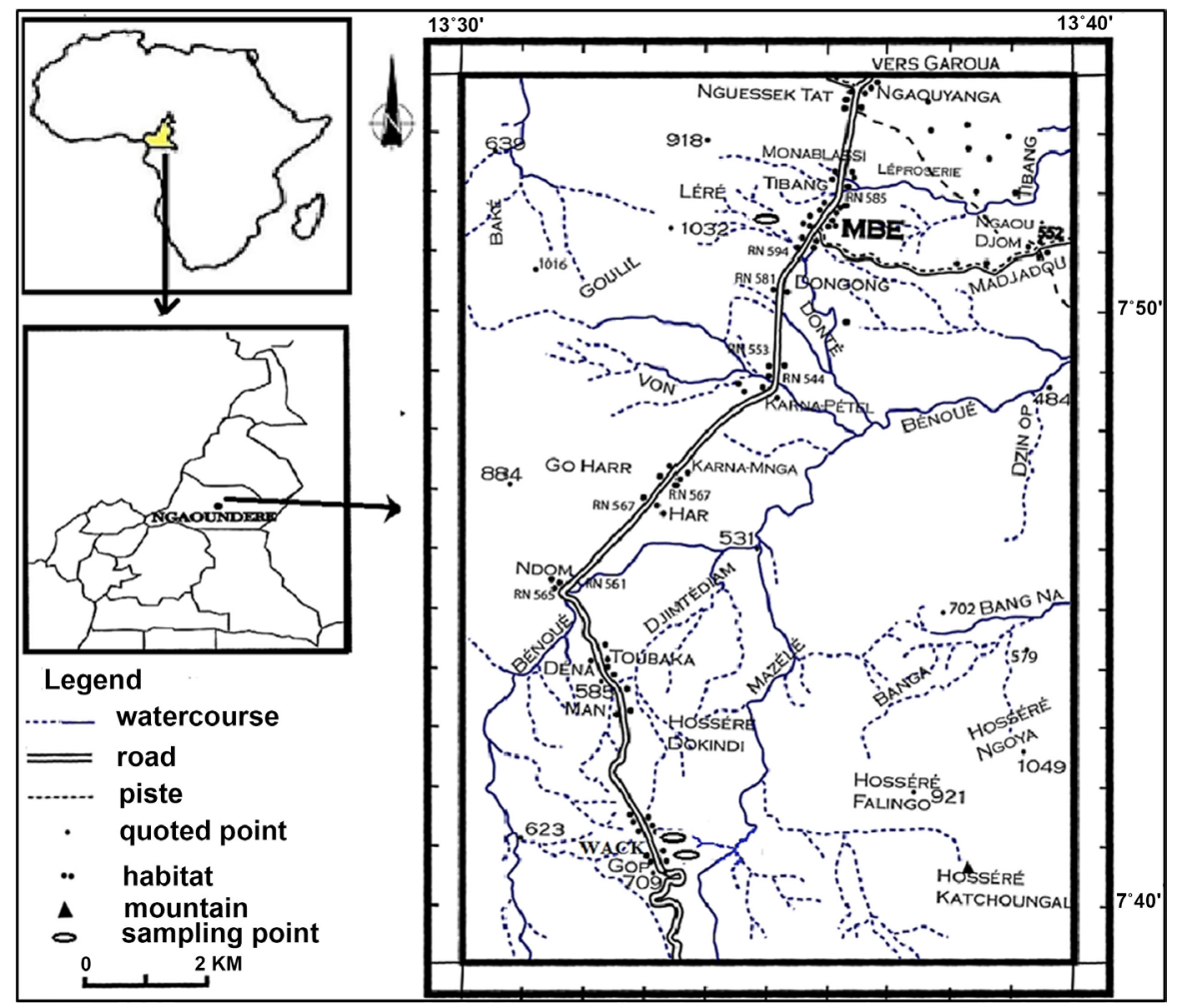

Figure 1. Location map of Mbé and Wack.

Wack and Mbé repose respectively on granites of Precambrian and gneiss from upper Cretaceous and Tertiary formations. The soils are classified as oxisols and ultisols [10]. These soils were mainly sandy and display a low exchangeable cations and exchangeable cations capacity (CEC). Wack and Mbé are located in the North of the Adamawa plateau with $1200 \mathrm{~m}$ altitude [11]. Most of the lands are between $500 \mathrm{~m}$ and $1100 \mathrm{~m}$ above the sea level (Figure 1). A positive correlation between relief and soil erosion by water in the zone is widely observed [12].

Soils samples were collected from topsoil ( $0-25 \mathrm{~cm}$ depth). Five soil samples were collected in Mbé on a gentle slope and six samples were collected in two toposequences with three samples each one in Wack (Figure 1). In each series, samples were collected according to land uses and position on the slope (Table $1)$.

\subsection{Laboratory Methods}

The sampled soils which were air-dried and sieved to pass through a $2 \mathrm{~mm}$ were analysed at the Institute of Science of the University of Leibniz, Hanover in Germany.

Particle size distribution was determined by the pipette method after dispersion with Na-hexametaphosphate and organic matter destruction by hydrogen peroxide and deferritisation with hydrochloric acid followed by $16 \mathrm{~h}$ of mechanical agitation using an end-over-end shaker. Soil $\mathrm{pH}$ water was measured 
Table 1. Land use with agricultural practices in sampling sites.

\begin{tabular}{ccccl}
\hline Sites & Sample code & Location & Land use & \multicolumn{1}{c}{ Agricultural practices } \\
\hline & MNV & Top & Natural Vegetation & Native vegetation, zero tillage, bushfires \\
Mbé & MCF & Midslope & Fallow & Zero tillage, bushfires \\
& MCC & Midslope & Yam culture & $\begin{array}{l}\text { Tractor ploughing, ridge, fertilizer } \\
\text { inputs, bushfires }\end{array}$ \\
& MCM & Footslope & Cassava culture & Manual tillage, fertilizers use, bushfires \\
& WCM & Top & Culture of Maize & Manual tillage, bushfires \\
Wack & WCY & Midslope & Culture of Yam & Manual tillage, ridge, fertilizer inputs, \\
(Slope 1) & bushfires
\end{tabular}

with a $\mathrm{pH}$ meter equipped with a glass electrode in 2/5 soil-water suspensions. The $\mathrm{pHCaCl}_{2}$ was determined in $2 / 5$ soil-water suspensions $+\mathrm{CaCl}_{2}$. Organic carbon (OC), nitrogen $(\mathrm{N})$ and sulphur (S) were determined by CHNS-O method (Vario EL III). The percentage of organic matter (OM) was calculated by multiplying the $\mathrm{OC}$ value by 1.724 and to determine the rate of OM degradation, $\mathrm{OC} / \mathrm{N}$ was calculated by dividing $\mathrm{OC}$ by $\mathrm{N}$ contents. Exchangeable cations $\left(\mathrm{Na}^{+}, \mathrm{K}^{+}, \mathrm{Mg}^{2+}, \mathrm{Ca}^{2+}, \mathrm{Al}^{3+}\right)$ were determined by extraction with silver thiourea and cation exchange capacity (CEC) was measured at soil $\mathrm{pH}$ by performing the Na-thiourea method. The percentage of base saturation was calculated as $(\mathrm{TEB} / \mathrm{CEC})^{\star} 100$. Amorphous and crystalline $\mathrm{Fe}$ and $\mathrm{Al}$ in the soil were extracted using ammonium oxalate and citrate-bicarbonate-dithionate (CBD). Soluble cations and anions were extracted with deionised water (1:10) and detected by Inductively Coupled Plasma (ICP-AES) and anions chromatography (DIONEX ICS-90).

\subsection{Data Analyses}

The water dispersible particles were determined followed the same method as particles size distribution described above except that no chemical dispersant was used and without organic matter destruction. The erodibility indices are calculated as follow [13] [14]:

$$
\begin{aligned}
& \text { Clay aggregation: } C A=T C\left(\mathrm{~g} \cdot \mathrm{kg}^{-1}\right)-W D C\left(\mathrm{~g} \cdot \mathrm{kg}^{-1}\right) \\
& \text { Clay floculation index: } C F I=T C\left(\mathrm{~g} \cdot \mathrm{kg}^{-1}\right)-\frac{W D C\left(\mathrm{~g} \cdot \mathrm{kg}^{-1}\right)}{T C\left(\mathrm{~g} \cdot \mathrm{kg}^{-1}\right)} \\
& \text { Clay dispersion ratio: } C D R=\frac{W D C\left(\mathrm{~g} \cdot \mathrm{kg}^{-1}\right)}{T C\left(\mathrm{~g} \cdot \mathrm{kg}^{-1}\right)}
\end{aligned}
$$




$$
\begin{aligned}
& \text { Dispersion ratio: } D R=\frac{W D C\left(\mathrm{~g} \cdot \mathrm{kg}^{-1}\right)+W D S\left(\mathrm{~g} \cdot \mathrm{kg}^{-1}\right)}{T C\left(\mathrm{~g} \cdot \mathrm{kg}^{-1}\right)+T S\left(\mathrm{~g} \cdot \mathrm{kg}^{-1}\right)} \\
& \text { Exchangeable sodium percentage: } E S P=\frac{\text { exchangeable } \mathrm{Na}^{+} * 100}{C E C} \\
& \text { Exchangeable sodium ratio } E S R=\frac{\text { exchangeable } \mathrm{Na}^{+}}{\text {exchangeable } \mathrm{Ca}^{+}+\mathrm{Mg}^{+}+\mathrm{K}^{+}}
\end{aligned}
$$

Total clay (TC) and total silt (TS) are clay fraction and silt fraction obtained by chemical dispersion. WDC is water dispersible clay and WDS is water dispersible silt.

The obtained data were been subjected statistically to simple correlation and regression analysis to determine the extent of relationships between soils parameters and their contribution to clay dispersion.

\section{Results and Discussion}

\subsection{Variation of Soil Properties According Land Use}

Specific properties of the soils and their classification are shown in Table 2 and Table 3.

The total clay (TC) varies from $6.54 \%(\mathrm{MCY})$ to $15.03 \%(\mathrm{MNV})$. The soils from Mbé and Wack are sandy loam (SL) (Table 2). The soil under native vegetation $(\mathrm{MNV})$ was most clayey; displayed the highest $\mathrm{pH}(\mathrm{pH}$ water $=6.68, \mathrm{pH}$ $\mathrm{CaCl}_{2}=5.70$ ), organic components and amorphous and crystalline elements (Table 3). As in Mbé, the soil on natural vegetation (WNV) from Wack, located at upslope presents the highest $\mathrm{Fe}$ content while the soil from the footslope (WCS) is the most clayey (14.74\% of clay) with higher organic matter content (1.88\%) and the highest $\mathrm{Al}$ content. However, the studied soils under yams (MCY, WCY) and cassava (MCC, WCC) both at Mbé and Wack are the sandiest, more acidic, poorest in organic components (Table 2), Fe and Al (Table 3).

The studied soils have low content in exchangeable cations $\mathrm{Ca}^{2+}(9.214$ 53.473 mmolc. $\left.\mathrm{kg}^{-1}\right), \mathrm{Mg}^{2+}\left(2.949\right.$ - 20.422 mmolc. $\left.\mathrm{kg}^{-1}\right), \mathrm{K}^{+}(0.813$ - 5.677 mmolc $\left.\cdot \mathrm{kg}^{-1}\right), \mathrm{Na}^{+}\left(0.065\right.$ - 0.457 mmolc $\left.\cdot \mathrm{kg}^{-1}\right), \mathrm{Al}^{3+}\left(0\right.$ - $\left.1.201 \mathrm{mmolc} \cdot \mathrm{kg}^{-1}\right)$, CEC (22.3 - $\left.118.57 \mathrm{mmolc} \cdot \mathrm{kg}^{-1}\right)$ and TEB/CEC (0.592 - 0.7753) which vary in conformity with texture (SL) and $\mathrm{pH}$ (Table 4). The most clayey soils (MNV, WCM, and WCS), less acidic, richer in $\mathrm{N}$ and $\mathrm{OM}$, have the highest exchangeable cations concentration and poorest in $\mathrm{Al}^{3+}$ (responsible for exchange acidity) than the sandiest soils (MCY, MCC, WCY, and WCC) which are the more acidic, more rich in $\mathrm{Al}^{3+}$ and poorest in the exchangeable cations (Table 4).

The soils soluble ions concentration are less than 1 mmolc. $\mathrm{kg}^{-1}(0-0.6$ mmolc $\left.\cdot \mathrm{kg}^{-1}\right)$ except $\mathrm{K}^{+}\left(0.27\right.$ - $\left.2.54 \mathrm{mmolc} \cdot \mathrm{kg}^{-1}\right)$ and $\mathrm{Ca}^{2+}\left(0.47-1.58 \mathrm{mmolc} \cdot \mathrm{kg}^{-1}\right)$ (Table 5). They also vary in accordance with textural class and land use (cereals, tubers). Their variation and those of electric conductivity $\left(6.9-24.7 \mu \mathrm{S} \cdot \mathrm{cm}^{-1}\right)$ and exchangeable cations were similar. MNV recorded the highest values of 
Table 2. Main physical characteristics, organic elements and sulphur.

\begin{tabular}{ccccccccccccc}
\hline Sample & Location & TC & TS & TSa & Texture & $\mathrm{pH} \mathrm{H}_{2} \mathrm{O}$ & $\mathrm{pH} \mathrm{CaCl}_{2}$ & $\mathrm{C}$ & $\mathrm{N}$ & $\mathrm{OM}$ & $\mathrm{C} / \mathrm{N}$ & $\mathrm{S}$ \\
\hline & & & $\%$ & & & & & & $\%$ & & \\
\hline MNV & Topslope & 15.027 & 28.779 & 56.194 & SL & 6.68 & 5.70 & 2.03 & 0.121 & 3.49 & 16.74 & 0.008 \\
MCF & Midslope & 7.635 & 21.232 & 71.133 & SL & 6.18 & 4.85 & 0.616 & 0.039 & 1.06 & 15.72 & 0.005 \\
MCY & Midslope & 6.540 & 20.354 & 73.106 & SL & 5.56 & 4.31 & 0.614 & 0.044 & 1.06 & 13.98 & 0.003 \\
MCC & Midslope & 7.898 & 22.691 & 69.411 & SL & 6.16 & 5.07 & 1.183 & 0.063 & 2.03 & 18.65 & 0.004 \\
MCM & Footslope & 8.646 & 20.662 & 70.691 & SL & 6.35 & 5.12 & 0.405 & 0.03 & 0.70 & 13.47 & 0.004 \\
WCM & Topslope & 9.040 & 22.909 & 68.051 & SL & 6.07 & 4.96 & 0.923 & 0.064 & 1.59 & 14.37 & 0.014 \\
WCY & Midslope & 7.719 & 220,45 & 70.236 & SL & 5.56 & 5.52 & 1.05 & 0.075 & 1.81 & 13.98 & 0.010 \\
WNV & Footslope & 7.913 & 24.154 & 67.933 & SL & 5.81 & 4.52 & 0.895 & 0.062 & 1.54 & 14.41 & 0.008 \\
WCC & Topslope & 8.139 & 19.275 & 72.586 & SL & 6.02 & 4.67 & 0.600 & 0.047 & 1.03 & 12.89 & 0.007 \\
WCF & Midslope & 13.259 & 23.887 & 62.853 & SL & 6.38 & 5.39 & 1.079 & 0.077 & 1.86 & 14.10 & 0.033 \\
WCS & Footslope & 14.735 & 26.929 & 58.337 & SL & 6.07 & 4.68 & 1.093 & 0.076 & 1.88 & 14.34 & 0.014 \\
\hline
\end{tabular}

$\mathrm{SL}=$ sandy-loamy.

Table 3. Distribution of $\mathrm{Fe}$ and $\mathrm{Al}$ in the soils.

\begin{tabular}{cccccccccc}
\hline Sample & Location & TC $(\%)$ & TSa (\%) & Feox $\left(\mathrm{g} \cdot \mathrm{kg}^{-1}\right)$ & Alox $\left(\mathrm{g} \cdot \mathrm{kg}^{-1}\right)$ & Fedith $\left(\mathrm{g} \cdot \mathrm{kg}^{-1}\right)$ & Aldith $\left(\mathrm{g} \cdot \mathrm{kg}^{-1}\right)$ & Fed $\left(\mathrm{g} \cdot \mathrm{kg}^{-1}\right)$ & Ald $\left(\mathrm{g} \cdot \mathrm{kg}^{-1}\right)$ \\
\hline MNV & Topslope & 15.027 & 56.194 & 1.29 & 0.40 & 19.81 & 1.72 & 21.10 & 2.12 \\
MCF & Midslope & 7.635 & 71.133 & 0.25 & 0.25 & 8.81 & 0.99 & 9.06 & 1.24 \\
MCY & Midslope & 6.540 & 73.106 & 0.56 & 0.21 & 5.24 & 0.79 & 5.80 & 1.00 \\
MCC & Midslope & 7.898 & 69.411 & 0.27 & 0.30 & 10.06 & 1.24 & 10.33 & 1.54 \\
MCM & Footslope & 8.646 & 70.691 & 0.24 & 0.22 & 6.24 & 0.85 & 6.48 & 1.07 \\
WCM & Topslope & 9.040 & 68.051 & 0.6 & 0.42 & 8.14 & 1.41 & 8.74 & 1.83 \\
WCY & Midslope & 7.719 & 70.236 & 1.66 & 0.37 & 4.74 & 0.82 & 6.40 & 1.19 \\
WNV & Foot slope & 7.913 & 67.933 & 1.48 & 0.34 & 4.47 & 0.8 & 5.95 & 1.14 \\
WCC & Topslope & 8.139 & 72.586 & 0.34 & 0.26 & 10.32 & 1.59 & 10.66 & 1.85 \\
WCF & Midslope & 13.259 & 62.853 & 0.47 & 0.32 & 14.04 & 2.11 & 14.51 & 2.43 \\
WCS & Foot slope & 14.735 & 58.337 & 0.51 & 0.46 & 16.23 & 2.59 & 16.74 & 3.05 \\
\hline
\end{tabular}

$\mathrm{ox}=$ oxalate, dith $=$ dithionite, $\mathrm{d}=\mathrm{ox}+$ dith.

Table 4. Distribution of exchangeable cations in the studied soils.

\begin{tabular}{|c|c|c|c|c|c|c|c|c|c|}
\hline \multirow[b]{2}{*}{ Sample } & \multirow[b]{2}{*}{$\mathrm{TC}(\%)$} & \multicolumn{8}{|c|}{ Exchangeable cations (mmolc $\cdot \mathrm{kg}^{-1}$ ) } \\
\hline & & TSa (\%) & $\mathrm{Ca}$ & $\mathrm{Mg}$ & $\mathrm{Na}$ & $\mathrm{K}$ & $\mathrm{Al}$ & CEC & TEB/CEC \\
\hline MNV & 15.027 & 56.194 & 53.473 & 20.422 & 0.457 & 2.018 & 0.00 & 118.57 & 0.644 \\
\hline $\mathrm{MCF}$ & 7.635 & 71.133 & 14.341 & 4.652 & 0.170 & 0.829 & 0.033 & 26.88 & 0.744 \\
\hline MCY & 6.540 & 73.106 & 9.214 & 2.949 & 0.130 & 0.905 & 0.845 & 22.30 & 0.592 \\
\hline MCC & 7.898 & 69.411 & 25.135 & 5.540 & 0.104 & 1.389 & 0.011 & 43.48 & 0.740 \\
\hline WCM & 9.040 & 68.051 & 22.238 & 6.836 & 0.091 & 2.938 & 0.200 & 42.18 & 0.761 \\
\hline WCY & 7.719 & 70.236 & 16.886 & 7.305 & 0.300 & 0.813 & 1.201 & 36.29 & 0.697 \\
\hline WNV & 7.913 & 67.933 & 18.93 & 3.973 & 0.235 & 1.013 & 1.179 & 34.25 & 0.705 \\
\hline WCC & 8.139 & 72.586 & 12.136 & 5.133 & 0.065 & 0.821 & 0.289 & 27.9 & 0.651 \\
\hline WCF & 13.259 & 62.853 & 33.668 & 9.193 & 0.222 & 2.378 & 0.000 & 58.64 & 0.775 \\
\hline
\end{tabular}

$\mathrm{TEB}=$ total exchangeable bases. 
Table 5. Distribution of soluble ions and electric conductivity in the soils.

\begin{tabular}{ccccccccccccccc}
\hline & \multicolumn{3}{c}{$\%$} & \multicolumn{4}{c}{ Soluble cations and anions $\left(\mathrm{mmolc} \cdot \mathrm{kg}^{-1}\right)$} & \multicolumn{3}{c}{$(\mu \mathrm{S} / \mathrm{cm})$} \\
\hline Sample & $\mathrm{TC}$ & $\mathrm{TSa}$ & $\mathrm{Na}^{+}$ & $\mathrm{NH}_{4}^{+}$ & $\mathrm{K}^{+}$ & $\mathrm{Mg}^{2}$ & $\mathrm{Ca}^{2+}$ & $\mathrm{Cl}^{-}$ & $\mathrm{NO}_{3}^{-}$ & $\mathrm{PO}_{4}^{3-}$ & $\mathrm{SO}_{4}^{2-}$ & $\mathrm{EC}^{2-}$ \\
\hline MNV & 15.027 & 56.194 & 0.483 & 0.094 & 0.422 & 0.601 & 1.575 & 0.172 & 0.060 & 0.12 & 0.135 & 24.3 \\
MCF & 7.635 & 71.133 & 0.287 & 0.072 & 0.367 & 0.272 & 0.775 & 0.082 & 0.021 & 0.044 & 0.133 & 9.2 \\
MCY & 6.540 & 73.106 & 0.252 & 0.100 & 0.583 & 0.23 & 0.74 & 0.073 & 0.140 & 0.101 & 0.142 & 12.1 \\
MCC & 7.898 & 69.411 & 0.300 & 0.000 & 0.822 & 0.321 & 1.125 & 0.141 & 0.000 & 0.041 & 0.183 & 16.0 \\
MCM & 8.646 & 70.691 & 0.235 & 0.083 & 2.539 & 0.181 & 0.745 & 0.282 & 0.077 & 0.051 & 0.385 & 21.4 \\
WCM & 9.040 & 68.051 & 0.217 & 0.133 & 1.172 & 0.189 & 0.990 & 0.183 & 0.073 & 0.212 & 0.179 & 17.0 \\
WCY & 7.719 & 70.236 & 0.626 & 0.000 & 0.533 & 0.346 & 1.020 & 0.102 & 0.135 & 0.000 & 0.196 & 19.5 \\
WNV & 7.913 & 67.933 & 0.383 & 0.000 & 0.428 & 0.14 & 0.475 & 0.133 & 0.000 & 0.035 & 0.09 & 10.4 \\
WCC & 8.139 & 72.586 & 0.152 & 0.072 & 0.272 & 0.173 & 0.525 & 0.059 & 0.023 & 0.000 & 0.042 & 6.9 \\
WCF & 13.259 & 62.853 & 0.226 & 0.117 & 1.078 & 0.411 & 1.420 & 0.234 & 0.176 & 0.104 & 0.233 & 24.7 \\
WCS & 14.735 & 58.337 & 0.204 & 0.044 & 0.283 & 0.181 & 0.675 & 0.158 & 0.074 & 0.041 & 0.069 & 7.7 \\
\hline
\end{tabular}

divalent cations $\left(\mathrm{Ca}^{2+}, \mathrm{Mg}^{2+}\right)$ and EC. MCC and WCC are the poorer in sulphate, phosphate, nitrate, ammoniac, chloride and sodium (Table 5).

The studied soils are acidic $(\mathrm{pH}<7)$. $\mathrm{C} / \mathrm{N}$ values which is ranged between 12 and 25 reveals that OM is less matured. Despite of their position, the most clayey samples (MNV, WCS) content approximately the double of clay fraction than sandiest samples under tubers (MCC, MCY, WCC, WCY) mainly located at footslope.

The sandy-loam soils of Mbé and Wack show that real and potential acidities were proportional to clay or sand contents. More a soil is sandy, more it is acidic. Then, from the more acidic or sandy to the less acidic (more clayey) in Mbé, we noted MCY, MCF, MCC, MCM (footslope), MNV (topslope); in Wack, there is, WCY, WNV, WCC, WCM, WCS, WCF (Table 2).

Disappearance of organic matter due to erosion and oxidation degrade soils and their agricultural potential aptitudes. Reduction of organic matter weakens organo-minerals stability which can cause soil impermeability by crusting increasing streaming and erosion. In addition, cultivations weaken soils through yielding by nutrients exportation and non-restitution of organic matter to soils. Organic matter plays an important role in soil aggregation and structuring and it informs on soil potential fertility. MCM has lowest organic matter content because cereal crops are generally used as substitute crops to yams. However, MNV recorded higher organic matter elements in spite of his topslope position because that it never ploughed and plant cover favours soil structural stability. But soil under tubers crops are impoverished by plants needs and more by ploughing and ridge.

Globally, cultivated soils are more acidic and sandy. However, those which are under tubers crops (yam, Cassava) are more acidic than those under cereals (maize, millet). The soils are low in crystalline $\mathrm{Fe}_{\mathrm{ox}}$ and $\mathrm{Al}_{\mathrm{ox}}$, amorphous $\mathrm{Fe}_{\mathrm{di}}$ and $\mathrm{Al}_{\mathrm{di}}$ which also vary with regard to texture and land use (Table 3). MNV is 
naturally richer in Fe which probably derived from rock (gneiss) weathering but WCS recorded more $\mathrm{Al}$ because of alteration, agricultural input and position on footslope. The CEC vary similarly to the exchangeable cations contents in the soils and in conformity with the clay ratio. Soils under yams culture are the less saturated and cultivated soils are more saturated than soils never cultivated (Table 4).

\subsection{Total Clay (TC), Water Dispersible Clay (WDC), Clay Dispersion Ratio (CDR) and Soil Erodibility}

The total clay (TC) of the studied soils varies from $65.4 \mathrm{~g} \cdot \mathrm{kg}^{-1}$ (MCY) to 150.27 $\mathrm{g} \cdot \mathrm{kg}^{-1}$ (MNV) while the WDC ranges between $34.92 \mathrm{~g} \cdot \mathrm{kg}^{-1}$ (MCY) and 121.75 $\mathrm{g} \cdot \mathrm{kg}^{-1}$ (MNV). The WDC was globally high and varied with regard to land use. It is noted that the not cropped soil mainly located at the upslope (MNV) recorded the highest WDC (Table 6). The CDR ranged between 0.45 and $0.84 \mathrm{~g} \cdot \mathrm{kg}^{-1}$.

In Mbé, the soil under natural vegetation (MNV) at topslope recorded the highest TC (150.27 g. $\left.\mathrm{kg}^{-1}\right)$, WDC (121.75 g. $\left.\mathrm{kg}^{-1}\right)$, CDR (0.81) while MCY (located at midslope) presented the lowest TC $\left(65.4 \mathrm{~g} \cdot \mathrm{kg}^{-1}\right)$, WDC $\left(47.46 \mathrm{~g} \cdot \mathrm{kg}^{-1}\right)$ and CDR (0.73) (Table 6). In Wack, it is WCS (on footslope) which presents the highest value of TC (147.35 $\left.\mathrm{g} \cdot \mathrm{kg}^{-1}\right)$ and WDC (112.49 $\left.\mathrm{g} \cdot \mathrm{kg}^{-1}\right)$. WCY at midslope under yam culture display slow TC (77.19 g. $\left.\mathrm{kg}^{-1}\right)$, WDC (34.92 $\left.\mathrm{g} \cdot \mathrm{kg}^{-1}\right)$ and CDR (0.45). However, in the first sequence, WCM (on topslope) has the highest TC (90.4 $\left.\mathrm{g} \cdot \mathrm{kg}^{-1}\right)$, WDC (50.90 g. $\left.\mathrm{kg}^{-1}\right), \mathrm{CDR}(0.56)$ and WCY (on midslope) has the lowest ones. In the second sequence at Wack, WCS (on footslope) recorded the highest TC (147.35 g. $\left.\mathrm{kg}^{-1}\right)$ and WDC (112.49 $\left.\mathrm{g} \cdot \mathrm{kg}^{-1}\right)$ but the lowest CDR (0.76). WCC (on topslope) presents the lowest TC $\left(81.39 \mathrm{~g} \cdot \mathrm{kg}^{-1}\right)$, WDC $\left(68.23 \mathrm{~g} \cdot \mathrm{kg}^{-1}\right)$ and the highest CDR (0.84) (Table 6).

The WDC and CDR are good estimators of soil susceptibility to water erosion. They express an ability of clays particles from soils to be eroded by water. Higher WDC and CDR mean high soil susceptibility to erosion [7] [18] [19] [20]. Hence, according WDC values, the not cropped soils both on topslope at Mbe is the more susceptible to erosion while those from Wack at footslope is the less erodible. This means that the slope has impact on soil susceptibility to erosion. It is also noted that WDC and TC were good estimators of soils erodibility [3] [6] [7] [8]. In fact, as observed, soils which are more clayey and those on topslope are more erodible than soils with less clays content. But those on midslope are generally more stable and show low CDR and WDC values.

\subsection{Dispersion Ratio (DR), Exchangeable Sodium Percentage (ESP), Exchangeable Sodium Ratio (ESR) and Soil Erodibility}

In Mbé, the DR varied from 0.85 to 0.89 ; ESP ranged from 0.22 to 0.83 and ESR varied from 0.001 to 0.017 . MCY (on midleslope) has a lowest DR (0.85) and a highest ESR (0.01). Then, MCC (on midleslope) has the highest DR (0.89), and lowest ESP (0.24), ESR (0.003). In Wack, the DR varied from 0.75 to 0.87 . In Wack, in the first sequence, WCM (on topslope) has highest DR (0.88) and 
Table 6. Erodibility indexes.

\begin{tabular}{|c|c|c|c|c|c|c|c|c|c|c|c|c|}
\hline \multicolumn{13}{|c|}{$\mathrm{g} \cdot \mathrm{kg}^{-1}$} \\
\hline Sample & Location & Land use & $\mathrm{TC}$ & WDC & TS & WDS & CA & CFI & CDR & DR & ESP & ESR \\
\hline $\mathrm{MNV}$ & Topslope & Non cultivated & 150.27 & 121.75 & 287.79 & 261.01 & 28.52 & 0.19 & 0.81 & 0.87 & 0.39 & 0.006 \\
\hline $\mathrm{MCF}$ & Midslope & Fallow & 76.35 & 57.43 & 212.32 & 192.80 & 18.92 & 0.25 & 0.75 & 0.87 & 0.63 & 0.009 \\
\hline MCY & Midslope & Cultivated & 65.40 & 47.46 & 203.54 & 180.06 & 17.94 & 0.27 & 0.73 & 0.85 & 0.58 & 0.01 \\
\hline MCC & Midslope & Cultivated & 78.98 & 60.88 & 226.91 & 210.69 & 18.10 & 0.23 & 0.77 & 0.89 & 0.24 & 0.003 \\
\hline MCM & Footslope & Cultivated & 86.46 & 64.46 & 206.62 & 183.99 & 22.00 & 0.25 & 0.75 & 0.85 & 0.34 & 0.005 \\
\hline WCM & Topslope & Cultivated & 90.40 & 50.90 & 229.09 & 230.64 & 39.50 & 0.44 & 0.56 & 0.88 & 0.22 & 0.002 \\
\hline WCY & Midslope & Cultivated & 77.19 & 34.92 & 220.45 & 196.81 & 42.27 & 0.55 & 0.45 & 0.78 & 0.83 & 0.010 \\
\hline WNV & Footslope & Non cultivated & 79.13 & 39.20 & 241.54 & 202.39 & 39.93 & 0.50 & 0.50 & 0.75 & 0.69 & 0.001 \\
\hline WCC & Topslope & Cultivated & 81.39 & 68.23 & 192.75 & 176.75 & 13.16 & 0.16 & 0.84 & 0.89 & 0.23 & 0.004 \\
\hline WCF & Midslope & Fallow & 132.59 & 102.9 & 238.87 & 219.42 & 29.69 & 0.22 & 0.78 & 0.87 & 0.38 & 0.005 \\
\hline WCS & Footslope & Cultivated & 147.35 & 112.49 & 269.29 & 242.49 & 34.86 & 0.24 & 0.76 & 0.85 & 0.44 & 0.017 \\
\hline
\end{tabular}

lowest ESP (0.22). Then, WCY (on midleslope) has highest ESP (0.83), ESR (0.01). In the second sequence, WCS (on footslope) has highest ESP (0.44), ESR (0.017) and lowest DR (0.85). While, WCC (on topslope) presents lowest ESP (0.23), ESR (0.004) and highest DR (0.89) values (Table 6). The DR is the ability of clay and silt to be dispersed by water. So, high DR means high susceptibility of the soil to erosion because of disorganization of their structure which facilitates the mobilization of fine particles [19]. However, ESP and ESR vary opposite to DR. This means that, $\mathrm{Na}^{+}$do not plays it dispersive role [7], because of very low contents in the soil.

\subsection{The Clay Aggregation (CA), Clay Flocculation Index (CFI) and Soil Erodibility}

The clay aggregation (CA) ranged between 13.16 and $42.27 \mathrm{~g} \cdot \mathrm{kg}^{-1}$ while the CFI varied between 0.16 and 0.55 . In Mbé, the more clayey soil (MNV) at topslope presents the highest CA (28.52 $\left.\mathrm{g} \cdot \mathrm{kg}^{-1}\right)$ and the low CFI (0.19) than MCY (on midslope) which presents the highest CFI (0.27). However, in Wack, it is WCS (on footslope) that presents the highest CA (34.86 g. $\left.\mathrm{kg}^{-1}\right)$, CFI (0.24) and the highest TC (147.35 g. $\left.\mathrm{kg}^{-1}\right)$ and WDC (112.49 $\left.\mathrm{g} \cdot \mathrm{kg}^{-1}\right)$ while, in the second toposequence, WCY (on midleslope) presents the highest CA $\left(42.27 \mathrm{~g} \cdot \mathrm{kg}^{-1}\right)$ and CFI (0.55) in accordance with its lowest TC (77.19 $\left.\mathrm{g} \cdot \mathrm{kg}^{-1}\right)$ and WDC (34.92 g. $\mathrm{kg}^{-1}$ ) (Table 6).

In Mbé, soil with higher clays content and not cropped (MNV on topslope) is more erodible than degraded soils with high values of sand. In Wack, on each toposequence, there are cultivated soils (WCM on topslope and WCS on footslope) more clayey, which are more erodible. However, in spite of their position, soils under culture of tubers (MCY and WCY on middle slope, WCC on topslope) are more erodible. Thus, contrary to land use, the gentle slope not really 
influences soils susceptibility to erosion. The clay aggregation is very low at upslope $\left(30 \mathrm{~g} \cdot \mathrm{kg}^{-1}\right)$ while in the middle and lower slopes these values are relatively high and similar. As CA, CFI are lowest in upslope soils. The CA and CFI is indicative of the ability of soils particles to be aggregated and flocculated or more stable. Higher CA or CFI means higher soil stability and thus lower erodibility. Thus, as indicated by WDC, CDR and DR, in this study, CA and CFI shows that: soils located at the up part of the toposequence are more erodible and the cropped soils located at the up part of the toposequence are more erodible and less stable than not cropped soils suggesting that agricultural practices and slope gradient increase their erodibility [19]. [19] Obtained similar results in the irrigated and flooded vertisols from the sudano-sahelian part of Cameroon.

\subsection{Relationships between Erodibility Indexes and Soils Properties}

Correlations between erodibility indexes and soil properties are presented in Table 7. The TC shows significant positive correlation with WDC $(r=0.94), \mathrm{pH}$ water $(r=0.7)$, organic components $(r=0.6-0.75)$, amorphous $\mathrm{Fe}_{\text {dith }}(r=0.9)$, amorphous $\mathrm{Al}_{\text {dith }}(\mathrm{r}=0.85)$, exchangeable $\mathrm{Ca}(\mathrm{r}=0.8), \mathrm{Mg}(\mathrm{r}=0.8)$ and CEC ( $\mathrm{r}$ $=0.8)$ (Table 7). The CA is positively correlated with CFI $(r=0.79)$, crystalline $\mathrm{Fe}_{\mathrm{ox}}(0.7)$ and crystalline $\mathrm{Al}_{\mathrm{ox}}(\mathrm{r}=0.76)$. Also, $\mathrm{CDR}$ is positively correlated with $\mathrm{DR}$ (0.78), WDC (0.7), ESP, $\mathrm{Na}$ and $\mathrm{Al}$ (Table 7). However, there is significant negative correlation between WDC and CFI $(r=-0.7)$; CA and CDR $(r=-0.79)$; CFI and CDR $(\mathrm{r}=-1.0)$ and DR $(\mathrm{r}=-0.78)$; $\mathrm{CDR}$ and $\mathrm{Fe}_{\mathrm{ox}}(\mathrm{r}=-0.7)$ and $\mathrm{Al}(\mathrm{r}=$ -0.75); $\mathrm{DR}$ and $\mathrm{Fe}_{\mathrm{ox}}(\mathrm{r}=-0.77), \mathrm{Al}(\mathrm{r}=-0.87)$. ESP and DR are also negatively correlated $(\mathrm{r}=-0.8)$ (Table 7).

Generally, OM is cementing particles agent. It has a capacity to bind mineral particles together developing soil structure. Intense tillage degrade soil structure and contribute to decrease OM content which holds particles together, enabling the surface soil to resist to the detachment forces of raindrop and flood [19]. In the current study, OM and sulphur show positive but not significant correlation with CA (Table 7). Despite its low content, it contribution on reducing clay dispersion can be important [3] [19].

$\mathrm{Fe}$ and $\mathrm{Al}$ can be flocculants by establishing linkage between clays and organic polymers or by acting as cement like gel on clayey particles surfaces. They increase cohesion [21] [22] [23] which contribute to reduce soils erodibility. Fe and $\mathrm{Al}$ (responsible for soils acidity) correlated positively with TC, WDC, CA and CFI. The CFI which express the stability of the soils shows negative correlation with WDC, CDR and DR (Table 7). This confirms that flocculation of clays is opposed to their dispersion. The significant positive correlation between CFI and CA means that clay flocculation leads to clay aggregation. So, this last results from the rearrangement of particles through flocculation and cementation [24]. The positive correlation between amorphous $\mathrm{Al}$ and Fe with WDC, CA, CFI and negative correlation with $\mathrm{CDR}$ and $\mathrm{DR}$ show that $\mathrm{Al}_{\text {ox }}$ and $\mathrm{Fe}_{\mathrm{ox}}$ contributes to soil aggregation (Table 7). Exchangeables $\mathrm{Ca}, \mathrm{Mg}, \mathrm{Na}$ and $\mathrm{Al}$ are positively 
Table 7. Correlations between erodibility indexes and soils properties.

\begin{tabular}{|c|c|c|c|c|c|c|c|c|}
\hline Variables & TC & WDC & $\mathrm{CA}$ & CFI & $\mathrm{CDR}$ & DR & ESP & ESR \\
\hline TC & 1 & 0.943 & 0.264 & -0.374 & 0.374 & 0.216 & -0.253 & 0.324 \\
\hline WDC & 0.943 & 1 & -0.073 & -0.66 & 0.66 & 0.446 & -0.401 & 0.317 \\
\hline $\mathrm{CA}$ & 0.264 & -0.073 & 1 & 0.791 & -0.791 & -0.641 & 0.403 & 0.052 \\
\hline CFI & -0.374 & -0.66 & 0.791 & 1 & -1 & -0.783 & 0.599 & -0.142 \\
\hline $\mathrm{CDR}$ & 0.374 & 0.66 & -0.791 & -1 & 1 & 0.783 & -0.599 & 0.142 \\
\hline $\mathrm{DR}$ & 0.216 & 0.446 & -0.641 & --0.783 & 0.783 & 1 & -0.803 & -0.029 \\
\hline ESP & -0.253 & -0.401 & 0.403 & 0.599 & -0.599 & -0.803 & 1 & 0.362 \\
\hline ESR & 0.324 & 0.317 & 0.052 & -0.142 & 0.142 & -0.029 & 0.362 & 1 \\
\hline pH water & 0.652 & 0.745 & -0.206 & -0.612 & 0.612 & 0.549 & -0.575 & -0.206 \\
\hline $\mathrm{N}$ & 0.747 & 0.615 & 0.453 & 0.010 & -0.010 & -0.035 & -0.003 & 0.080 \\
\hline $\mathrm{OM}$ & 0.690 & 0.600 & 0.330 & -0.069 & 0.069 & 0.052 & -0.066 & 0.021 \\
\hline$S$ & 0.559 & 0.442 & 0.391 & -0.009 & 0.009 & 0.073 & -0.124 & 0.005 \\
\hline $\mathrm{Fe}_{\mathrm{Ox}}$ & 0.083 & -0.161 & 0.711 & 0.692 & -0.692 & -0.774 & 0.636 & -0.039 \\
\hline $\mathrm{Al}_{\mathrm{ox}}$ & 0.644 & 0.403 & 0.759 & 0.316 & -0.316 & -0.146 & -0.023 & 0.220 \\
\hline $\mathrm{Fe}_{\text {dith }}$ & 0.909 & 0.961 & -0.063 & -0.622 & 0.622 & 0.503 & -0.423 & 0.258 \\
\hline $\mathrm{Al}_{\text {dith }}$ & 0.853 & 0.848 & 0.097 & -0.474 & 0.474 & 0.424 & -0.446 & 0.369 \\
\hline $\mathrm{Fe}_{\mathrm{d}}$ & 0.923 & 0.950 & 0.012 & -0.553 & 0.553 & 0.425 & -0.359 & 0.255 \\
\hline $\mathrm{Al}_{\mathrm{d}}$ & 0.866 & 0.831 & 0.186 & -0.395 & 0.395 & 0.371 & -0.413 & 0.368 \\
\hline $\mathrm{Ca}$ & 0.830 & 0.769 & 0.255 & -0.246 & 0.246 & 0.195 & -0.229 & -0.038 \\
\hline $\mathrm{Mg}$ & 0.825 & 0.771 & 0.238 & -0.247 & 0.247 & 0.186 & -0.143 & 0.137 \\
\hline $\mathrm{Na}$ & 0.620 & 0.482 & 0.461 & 0.122 & -0.122 & -0.348 & 0.426 & 0.254 \\
\hline $\mathrm{K}$ & 0.153 & 0.155 & 0.009 & -0.127 & 0.127 & 0.187 & -0.433 & -0.248 \\
\hline $\mathrm{Al}$ & -0.385 & -0.570 & 0.498 & 0.748 & -0.748 & -0.865 & 0.753 & 0.160 \\
\hline CEC & 0.818 & 0.773 & 0.212 & -0.271 & 0.271 & 0.185 & -0.204 & 0.019 \\
\hline $\mathrm{Na}^{+}$ & -0.007 & -0.180 & 0.498 & 0.562 & -0.562 & -0.597 & 0.660 & 0.051 \\
\hline $\mathrm{NH}_{4}^{+}$ & 0.268 & 0.344 & -0.191 & -0.388 & 0.388 & 0.582 & -0.462 & -0.075 \\
\hline $\mathrm{K}^{+}$ & -0.106 & -0.089 & -0.059 & -0.029 & 0.029 & 0.122 & -0.336 & -0.307 \\
\hline $\mathrm{Mg}^{2+}$ & 0.528 & 0.539 & 0.020 & -0.249 & 0.249 & 0.209 & 0.010 & 0.015 \\
\hline $\mathrm{Ca}^{2+}$ & 0.544 & 0.520 & 0.122 & -0.192 & 0.192 & 0.331 & -0.199 & -0.100 \\
\hline $\mathrm{Cl}^{-}$ & 0.453 & 0.384 & 0.243 & -0.087 & 0.087 & 0.091 & -0.369 & -0.204 \\
\hline $\mathrm{NO}_{3}^{-}$ & 0.225 & 0.153 & 0.233 & 0.084 & -0.084 & -0.045 & 0.206 & 0.351 \\
\hline $\mathrm{PO}_{4}^{3-}$ & 0.254 & 0.184 & 0.228 & 0.025 & -0.025 & 0.354 & -0.393 & -0.251 \\
\hline $\mathrm{SO}_{4}^{2-}$ & -0.095 & -0.097 & -0.001 & 0.045 & -0.045 & 0.040 & -0.111 & -0.204 \\
\hline EC & 0.350 & 0.281 & 0.235 & 0.028 & -0.028 & 0.063 & -0.118 & -0.269 \\
\hline
\end{tabular}

correlated to CA (Table 7). They have stabilizing and aggregating effect. $\mathrm{Na}$ is not dispersive agent as usual. Then, $\mathrm{K}$ negatively correlated to $\mathrm{CFI}$ and positively to CDR and DR is dispersive agent (Table 7) [7] [13] [19].

Despite $\mathrm{Na}^{+}$is positively correlated to ESP, globally, it is no significant between erodibility indexes and soluble ions and EC because their low contents in these soils. These elements are washed out or lixiviate due to agricultural practices (Table 7). Clay dispersion normally increases with exchangeable $\mathrm{Na}^{+}$(ESP) content [25]. However, [26] postulate that clay dispersion was affected by in- 
creasing of exchangeable $\mathrm{Na}^{+}$. In this study, $\mathrm{K}^{+}$and $\mathrm{NH}_{4}^{+}$are positively correlated to $\mathrm{CDR}$ and $\mathrm{DR}$, but $\mathrm{Na}^{+}$and $\mathrm{NO}_{3}^{-}$are positively correlated to $\mathrm{CA}$ and CFI. So, $\mathrm{K}^{+}$and $\mathrm{NH}_{4}^{+}$are dispersive then $\mathrm{Na}^{+}$and $\mathrm{NO}_{3}^{-}$are aggregative. But $\mathrm{Na}$ and EC not significantly correlated to erodibility indexes (Table 7). Hence, they are not more influencing clay dispersion.

In cultivated soils, the matrix and structure of the soils is regularly disorganized by labour. Conventional tillage which inverts soil is generally accompanied by a loss of organic matter which binds soils particles together. Then soils cultivated by tubers (yams, cassava) are less erodible than those under cereals (maize, sorghum). Finally, cultural practices influence stability of aggregates and carbon ratio of the soils [9] [27] [28].

Considering obtained data and correlations coefficient, clay dispersion of sandy soils of Mbé and Wack is mostly caused by soil utilization. Soils under tubers culture (Yam, Cassava) are cultivated during six months (august to February); they are the most acidic, less fertile, less saturated and most erodible. Thus, sandier soil is less erodible due to its heavy coarse materials which are low soluble and which cannot constitute suspension that can be easily mobilized. Consequently, most sandy (cultivated) soils that are already eroded are less erodible than the more clayey (never cultivated) soils. Soils under tubers culture are poorer in clay than soils under cereals (maize, millet) sometimes richer than never cultivated soils.

\section{Conclusion}

The study shows that soils of Mbé and Wack are sandy-loam and gravelly. They are naturally acidic and poor in nutrients. In each studied series of soils sampled, soils under natural vegetation and under cereals crops are more clayey and more erodible than those under tubers crops which are sandier. Soil properties and erodibility indexes show that the sandiest and most acidic soils are under tubers culture (yams, cassava) which were already eroded, lowest in nutrients and organic matter comparatively to soils under cereals (maize, sorghum). It is appeared that the more clayey soils were more erodible than the sandy ones. Thus, soil erodibility is influenced by texture and agricultural practices such as ridging, fallow after three years maximum for yam crops. So, soils are degraded by human being through cultural practices (burning land, ridging). In fact, low slope would have little impact on the variation of physico-chemical parameters. Insufficient plant cover, labour technics (yielding, ridge, ploughing), bushfires increase loss of clay particles and consequently loss of physico-chemical characteristics (OM, CEC). Studied soils showed that as $\mathrm{C}, \mathrm{N}$, organic matter $(\mathrm{OM})$ and exchangeable $\mathrm{Ca}, \mathrm{Mg}, \mathrm{Na}, \mathrm{Al}$ are globally follow clay distribution and contributed in aggregation and soil stabilization. Exchangeable $\mathrm{K}$, soluble $\mathrm{K}^{+}$and $\mathrm{NH}_{4}^{+}$ are dispersive agents. As $\mathrm{OM}$, amorphous $\mathrm{Al}$ and $\mathrm{Fe}$ contribute to reduce clay dispersion. The soluble ions are in low contents and do not really influence soil dispersion. The used erodibililty indexes can be a reliable tool for determination 
of potential erosion in agricultural system and for avoidance of crop failing and soil conservation strategy. Soils which are more clayey and those on top of slope are more erodible than soils with less clays content. The slope and land use impact soils erodibility because soils in upslope are less aggregated and flocculated and the cropped soils at the up part of the toposequence are more erodible and less stable than not cropped soils. But those on middle slope are generally more stable and show low CDR and WDC values. This suggests that agricultural practices and slope gradient increase the soils erodibility. Statistical analyses revealed that amorphous $\mathrm{Al}$ and $\mathrm{Fe}$ are main elements which limit soils erodibility.

\section{Conflicts of Interest}

The authors declare no conflicts of interest regarding the publication of this paper.

\section{References}

[1] Lal, R. (2000) Physical Management of Soils in the Tropics: Priorities for the 21st Century. Soil Science, 165, 191-207. https://doi.org/10.1097/00010694-200003000-00002

[2] Salako, F.K. (2001) Structural Stability of an Alfisol under Various Fallow Management Practices in Southwestern Nigeria. Land Degradation \& Development, 12, 319-328. https://doi.org/10.1002/ldr.453.abs

[3] Igwé, C.A. (2003) Erodibility of Soils of the Upper Rainforest Zone, Southern Nigeria. Land Degradation \& Development, 14, 323-334. https://doi.org/10.1002/ldr.554

[4] Pieri, C., Charma, N. and Valencia, I. (1998) Investing in Land Fertiliy, a Major Chalenge for the Subsaharan Africa. In: Intesification agricole au sahel, Karthala. Paris, 877-894.

[5] Ministry of Environment and Nature Protection (2006) The National Action Plan to Combat Desertification in Cameroon (PAN/LCD).

[6] Igwe, C.A. (2001) Clay Dispersion of Selected Aeolian Soils of Northern Nigeria in Relation to Sodicity and, Organic Carbon Content. Arid Land Research and Management, 15, 147-155. https://doi.org/10.1080/15324980151062788

[7] Igwe, C.A. (2005) Erodibility in Relation to Water Dispersible Clay for Some Soils of Eastern Nigeria, Department of Soil Science, University of Nsukka, Nigeria. Land Degradation \& Development, 16, 87-96. https://doi.org/10.1002/ldr.647

[8] Seta and Karathanasis, A.D. (1996) Water Dispersible Colloids and Factors Influencing Their Dispersibility from Soil Aggregates. Geoderma, 74, 255-266. https://doi.org/10.1016/S0016-7061(96)00066-3

[9] Barthes, B., Albrecht, A., Asseline, J., De Noni, G., Roose, E. and Viennot, M. (1998) Agricultural Practices and Soil Erodibility in the Rougiers de Camarès (Aveyron). 159-161.

[10] Brabant, P. and Gavaud, M. (1985) Soils and Land Ressources in Northern Cameroon. Coll Notice Explicative 103. MESIRES-IRA Yaounde, ORSTOM, 285 p.

[11] Jean-François, D. (1997) Structural Studies of the Norther and Southern Borders of Adamawa: Influenceof the Atlantic Context. Ministry of Territorial Administration and Decentralisation. ORSTOM, Lima, Apartado 18 7209. Géodynamique, 2, 55-66. 
[12] Souaibou, M.O.J., Elimbi, A., Ekodeck, G.E. and Kamgang, V.K.B. (2015) Motphological and Geochemical Characteristics of Alteration Coast Developped on Granitoids in the Adamawa Region (Cameroon). European Scientific Journal, 11, 187-204.

[13] Nguetnkam, J.P. and Dultz, S. (2014) Clay Dispersion in Typical Soils of North Cameroon as a Function of $\mathrm{pH}$ and Electrolyte Concentration. Land Degradation \& Development, 25, 153-162. https://doi.org/10.1002/ldr.1155

[14] Igwe, C.A., Zarei, M. and Stahr, K. (2009) Colloidal Stability in Some Tropical Soils of Southeastern Nigeria as Affected by Iron and Aluminium Oxides. Catena, 77, 232-237. https://doi.org/10.1016/j.catena.2009.01.003

[15] Dong, A., Chester, G. and Simsiman, G.V. (1983) Soil Dispersibility. Soil Science, 136, 208-212. https://doi.org/10.1097/00010694-198310000-00002

[16] Middleton, H.E. (1930) Properties of Soils Which Influence Soil Erosion. The United States Department of Agriculture, Washington DC, 178 p.

[17] Rhoades, J.D. and Oster, J.D. (1986) Solute Contain. In: Klute, A., Ed., Method of Soil Analysis, Part I, American Society of Agronomy, Madison, WI, 985-1006.

[18] Nguetnkam, J.P. and Dultz, S. (2011) Soil Degradation in Central North Cameroon: Water Dispersable Clay in Relation to Surface Charge in Oxisol A and B Horizons. Soil \& Tillage Research, 113, 38-47. https://doi.org/10.1016/j.still.2011.01.006

[19] Basga, D.S., Tsozue, D., Temga, J.P., Balna, J. and Nguetnkam, J.P. (2018) Land Use Impact on Clay Dispersion/Flocculation in Irrigated and Flooded Vertisols from Northern Cameroon. International Soil and Water Conservation Research, 6, 237-244. https://doi.org/10.1016/j.iswcr.2018.03.004

[20] Bajracharya, R.M., Elliot, W.J. and Lal, R. (1992) Interrill Erodibility of Some Ohio Soils Based on Field Rainfall Simulation. Soil Science Society of America Journal, 56, 267-272. https://doi.org/10.2136/sssaj1992.03615995005600010041x

[21] Römkens, M.J.M., Roth, C.B. and Nelson, D.W. (1977) Erodibility of Selected Clay Subsoils in Relation to Physical and Chemical Properties. Soil Science Society of America Journal, 41, 954-960. https://doi.org/10.2136/sssaj1977.03615995004100050030x

[22] Le Bisonnais, Y. and Singer, M. (1993) Seal Formation, Runofff and Interill Erosion from Seventeen California Soils. Soil Science Society of America Journal, 57, 224-229. https://doi.org/10.2136/sssaj1993.03615995005700010039x

[23] Abiven, S. (2004) Relationship between the Characteristics of the Organic Matter, the Dynamic of Their Decomposition and the Evolution of the Structural Stability of the Soil. Thesis of ENSA-Rennes, $262 \mathrm{p}$.

[24] An, S.-S., Huang, Y.-M., Zheing, F.L. and Yang, J.G. (2008) Aggregate Characteristics during Natural Revegetation on the Loess Plateau. Pedosphere, 18, 809-816. https://doi.org/10.1016/S1002-0160(08)60077-6

[25] Shainberg, I. and Letey, J. (1984) Response to Soil Sodic and Salilne Conditions. Hilgradia, 52, 1-57. https://doi.org/10.3733/hilg.v52n02p057

[26] Levy, G.J. and Torrento, J.R. (1995) Clay Dispersion and Macroaggregate Stability as Affected by Exchangeable Potassium and Sodium. Soil Science, 160, 352-358. https://doi.org/10.1097/00010694-199511000-00004

[27] Curtin, J.S. and Mullen, G.J. (2007) Physical Properties of Some Intensively Cultivated Soil of Ireland Amended with Spent Mushroom Compost. Land Degradation \& Development, 18, 355-368.

[28] Arbelo, C.D., Rodriguez-Rodriguez, A., Guerra, J.A., Mora, J.L., Notario, J.S. and 
Fuentes, F. (2005) Soil Degradation Process and Plant Colonization in Abandoned Terraced Fields Overlying Pumice Tuffs. Land Degradation \& Development, 17, 571-588. https://doi.org/10.1002/ldr.735 